\title{
Assessing Subjective Age and Adjustment to Aging in a Portuguese and German Older Population: A Comparative Multiple Correspondence Analysis
}

\author{
Sofia von Humboldt ${ }^{1}$, Isabel Leal ${ }^{1} \&$ Filipa Pimenta ${ }^{1}$ \\ ${ }^{1}$ Research Unit in Psychology and Health, I \& D, ISPA - Instituto Universitário, Lisbon, Portugal \\ Correspondence: Sofia von Humboldt, Research Unit in Psychology and Health, I \& D, ISPA - Instituto \\ Universitário. Rua Jardim do Tabaco, 34, 1149-041 Lisboa, Portugal. Tel: 351-21-881-170. E-mail: \\ sofia.humboldt@gmail.com
}

Received: April 8, 2012 Accepted: May 8, 2012 Published: June 1, 2012

doi:10.5539/ijps.v4n2p141 URL: http://dx.doi.org/10.5539/ijps.v4n2p141

\begin{abstract}
Purpose: This study aims at examining the contributors to adjustment to aging (AtA) and subjective age (SA) identified by older adults and to investigate the latent constructs that can work as major determinants in AtA and SA in an older Portuguese and German population.

Method: Measures were completed, using a variety of appropriate methods, including demographics and interviews. Complete data were available for 102 older adults aged between 74-100 years $(M=81.2 ; S D=6.70)$. Data was subjected to content analysis. Representation of the associations and latent constructs were analyzed by a Multiple Correspondence Analysis (MCA).

Results: Findings showed a model for each nationality. SA and AtA for Portuguese elderly were explained by a three-factor overall model: "active", "concentrated" and "attuned". A three-dimension overall model formed by "harmonized", "focused" and "young-at-heart" was indicated as a best-fit solution for German elderly.

Conclusion: SAis differently related to AtA in older adults in both samples. The findings presented in this paper highlighted the under-developed potential of an adjustment and age overall model for this population.
\end{abstract}

Keywords: adjustment to aging, subjective age, multiple correspondence analysis, German, Portuguese

\section{Introduction}

Perhaps, one of the most remarkable demographic developments in modern times is the progressive demographic aging of the older population itself. In particular, the oldest old segment is growing faster than its younger segment (Gwozdz \& Sousa-Poza, 2009).

Alongside its incipient decline in numbers, the second strand to Europe's demographic weakness is the shrinking share of young people and growing share of older people in its population (Immerfall \& Therborn, 2011).

Indeed, according to United Nations Population Division's (2002) projections, in Germany, about 6 million inhabitants are over the age of 75 ( $7.1 \%$ of the population), a figure projected to increase to over 13 million ( $18.6 \%$ of the population) by 2050 .

In Portugal, German foreign community corresponded to $7.5 \%$ of the total foreign community. Moreover, the second most important region of location of the foreign community in Portugal is the Algarve with 13\% (Organization for Economic Co-Operation and Development, 2001). To date, little attention has been paid to older Germans living in Portugal in the literature.

Moreover, it is estimated that, in Portugal, in 2020 the elderly will represent $18.1 \%$ of the population and the young $16.1 \%$. Additionally, their social and psychological condition is mostly unknown (Instituto Nacional Estatística, 2005; World Health Organization Quality of Life Assessment Group, 2011).

Adjustment was initially described by Cattell (1950) as the goodness of internal arrangements by which an adaptation is maintained. Recent developments on the scientific study of adjustment to aging (AtA), conceptualized it, according to identity process theory, as involving the three processes of identity assimilation (maintaining self-consistency), identity accommodation (making changes in the self), and identity balance (maintaining a sense of self but changing when necessary) (Sneed \& Whitbourne, 2003) whereas according to 
Brandstädter and Greve's model, adjustment of a person's goals and aspirations in the face of age-related challenges corresponds to what the authors named of 'accommodation' (Brandtstädter \& Rothermund, 2003).

AtA is a relevant and proximate concept, yet distinct, from subjective well-being and quality of life, previously defined and validated in the gerontological literature. It is a multi-dimensional function of the dynamic interaction of elements such as autonomy, control, self-acceptance, personal growth, positive social network and purpose in life (Bauer \& McAdams, 2004; Keyes, Shmotkin \& Ryff, 2002; Ryff, 1989; Slangen-Dekort, Midden, Aarts \& Wagenberg, 2001; Staudinger \& Kunzmann, 2005). Regarding subjective well-being, it is a construct composed by two cognitive and affective (hedonic) facets: life satisfaction and affective balance, respectively (Diener, Suh, Lucas, \& Smith, 1999; Kesebir \& Diener, 2010; Pavot \& Diener, 2004), whereas quality of life is defined as an individual's perception of their position in life, in the context of the culture and value systems in which they live and in relation to their goals, expectations, standards and concerns (World Health Organization Quality of Life Assessment Group, 1995). Additionally, measures of well-being and quality of life have become popular outcome measures and a key consideration for policy-makers (Al-Janabi, Flynn \& Coast, 2012; Antonovsky, 1987; Diener, Emmons, Larsen, \& Griffin, 1985; Fernández-Ballesteros, 2010; Hancock, Labonte, \& Edwards, 1999; Low \& Molzahn, 2007; Ranzijn, 2002; Smith, Borchelt, Maier \& Jopp, 2002; Ware \& Sherbourne, 1992; Watson, Clark \& Tellegen, 1988). In spite of the findings described above, the study of AtA remains at the periphery of gerontological literature (Kozma, Stones \& McNeil, 1991).

Moreover, how old a person feels, designates subjective age (SA) (Barak, 2009; Barrett, 2005; Kleinspehn-Ammerlahn, Kotter-Grühn \& Smith, 2008; Montepare, 2009). In addition, SA was found to contribute to subjective health, memory self-efficacy, and life satisfaction, regardless of the chronological age (Stephan, Caudroit \& Chalabaev, 2011), which is consistent with studies showing that older individuals' own evaluation of their age is a better predictor of psychological functioning than an objective count of chronological years (Montepare, 2009; Schafer \& Shippee, 2010).

In past decades, research on the health and functioning of older adults has tended to focus on the prediction of negative outcomes, such as morbidity, mortality, disability and dependence (Boult, Kane, Louis, Boult \& McCaffrey, 1994; Maddox \& Clark, 1992; Pinsky et al., 1985) or has been developed with samples limited to frail individuals (Manton, Stallard, \& Corder, 1995; Wolinsky, Stump, Callahan \& Johnson, 1996). Considering that the construct of health does not imply the absence of illness but the attempt of maximum functionality of the individual (Antonovsky, 1987; Eriksson \& Lindstrom, 2006), the concept of "adjustment and age" is pertinent to a salutogenic approach focussed on the well-being, health, and adapted functioning of older adults (Brandtstädter \& Rothermund, 2003; Eriksson \& Lindstrom, 2006; Slangen-Dekort, Midden, Aarts \& Wagenberg, 2001;Schafer \& Shippee, 2010; Staudinger \& Kunzmann, 2005).

Considering that self-perception of aging is defined as a personal evaluation of one's own aging and that cultural and ethnical differences may influence the process of AtA (Barak, 2009; Torres, 2003), in-depth narrative interviews allow to uncover the uniqueness of older adults' experiences concerning the multi-dimensional context of aging well. Instead of being measured based on the theoretical assumptions or on the researchers' own definitions, we assert that to have a better understanding of what actually constitutes one's perception of AtA and SA, it is essential to listen and to explore older adults' narratives (Moser, Spagnoli \& Santos-Eggimann, 2011).

We found no previous research for an overall model that joins the concepts of "adjustment" and "age". Thus, this paper aims at making a relevant contribution to the existing literature by: (a) eliciting categories that had impact on Portuguese and German older adults' AtA and SA; (b) investigating latent constructs that can work as major contributors for AtA and SA and (c) examining the potential explanatory mechanisms of the overall model "adjustment and age". Results suggest that the hypothesized link between the two concepts may exist.

\section{Method}

\subsection{Participants}

The total sample comprised 102 eligible non-institutionalized individuals, aged 74 and over $(M=81.2 ; S D=6.70$; range $74-100$ ), $58.8 \%$ female, $67.6 \%$ married, $50.0 \%$ German and $66.7 \%$ professionally active. The sampling of participants was based on the availability of respondents, through local and art community centres list-serves, in the Algarve region. Older adults were included when concurrent severe mental disorders, according to DSM-IV, were not diagnosed, and excluded if they had difficulty in completing the Mini-Mental State Examination (MMSE).(Folstein, Folstein \& McHugh, 1975). Table 1 shows the characteristics of the interview informants. 
Table 1. Distribution of the study's participants according to socio demographic and health-related characteristics

\begin{tabular}{|c|c|c|c|c|}
\hline & \multicolumn{2}{|c|}{ German } & \multicolumn{2}{|c|}{ Portuguese } \\
\hline & $N$ & $\%$ & $n$ & $\%$ \\
\hline$N$ & \multicolumn{2}{|l|}{51} & \multicolumn{2}{|l|}{51} \\
\hline $\operatorname{Age}(M ; S D)$ & \multicolumn{2}{|c|}{$80.1(6.526)$} & \multicolumn{2}{|c|}{$81.4(6.931)$} \\
\hline \multicolumn{5}{|l|}{ Gender } \\
\hline Male & 18 & 35.3 & 24 & 47.1 \\
\hline Female & 33 & 64.7 & 27 & 52.9 \\
\hline \multicolumn{5}{|l|}{ Education } \\
\hline Primary school & 4 & 7.8 & 14 & 27.5 \\
\hline Middle school & 6 & 11.8 & 9 & 17.6 \\
\hline High school & 32 & 62.8 & 20 & 39.2 \\
\hline University degree or higher & 9 & 17.6 & 8 & 15.7 \\
\hline \multicolumn{5}{|l|}{ Marital Status } \\
\hline Married or in a relationship & 34 & 66.7 & 35 & 68.6 \\
\hline Single & 3 & 5.9 & 3 & 5.9 \\
\hline Widowed & 14 & 27.4 & 13 & 25.5 \\
\hline \multicolumn{5}{|l|}{ Professional Status } \\
\hline Active & 36 & 70.6 & 32 & 62.7 \\
\hline Inactive & 15 & 29.4 & 19 & 37.3 \\
\hline \multicolumn{5}{|l|}{ Family Annual Income } \\
\hline$\leq 10,000 €$ & 3 & 5.9 & 6 & 11.8 \\
\hline $10,001-20,000 €$ & 2 & 3.9 & 14 & 27.4 \\
\hline $20,001-37,500 €$ & 7 & 13.7 & 15 & 29.4 \\
\hline $37,501-70,000 €$ & 26 & 51.0 & 6 & 11.8 \\
\hline$\geq 70,001 €$ & 13 & 25.5 & 10 & 19.6 \\
\hline \multicolumn{5}{|l|}{ Perceived Health } \\
\hline Good & 26 & 51.0 & 30 & 58.8 \\
\hline
\end{tabular}

Note. Total sample: $n=102 ; S D=$ standard deviation.

\subsection{Measures and Procedure}

\subsubsection{Data Collection}

Semi-structured interviews based on an interview guide were conducted in the participants' own homes. Each interview was performed individually and began with a set of straightforward background questions, to find out about the informant's living arrangements, health, nationality, age, religion, family, education and work, followed by two open-ended questions that were created in order to be bias free and to allow any kind of narrative about each theme, as well as to facilitate the fluency of the participants' narratives about their perceptions: "How do you feel about your age?" and "I would like to understand what, in your point of view, contributes to your adjustment to aging in this phase of your life". These questions were elaborated to address two core areas: SA and AtA. The interview guide was used to ensure that basic questions were addressed, but the primary aim of the interview was to engage the participants in an in-depth interactive dialogue, during which richly descriptive responses would have the optimal possibility of emerging. Thus, emphasis was placed on the collaborative nature of the interview and the importance of the participants conveying how they saw and 
interpreted their perceptions. The interviews were conducted in the language of the participant's choice, necessary to enable full expression of their ideas and emotions. This allowed the questioning to be interactive and responsive to the participants' language and perceptions.

Moreover, the approach to the analysis was based on an overarching concern for reflecting the participants' perceptions. All interviews were conducted and audio-recorded by the same researcher $(\mathrm{SvH})$ who had no previous relationship with the participants. The interviews lasted between 40-90 minutes, with the open-ended questions taking 30-70 minutes to complete. Upon completion of the interview, participants were asked to evaluate the schedule and the interview process. This evaluation included questions about the length of the interview and the appropriateness and relevance of questions asked. Participants were also asked to identify any questions that they found difficult to answer or offensive.

\subsubsection{Data Analysis}

Data was analyzed, employing content analysis and using the following procedure: a) development of major emergent categories, mutually exclusive, that reflected the 102interviews, for each one of the two pre-existing categories: SA and contributors to AtA; b) creation a list of coding cues; c) analysis of verbatim quotes and best fit characterizations for a given emergent category d) definition of sub-categories, within and across the narratives, while preserving the principle of homogeneity of the category and e) derivation of major emergent categories until the point of theoretical saturation was reached (Bardin, 2007; Morse, 1995).

Our sub-categories and categories' structure was then subjected to an external review and critical feedback was obtained from reviewers with experience with older adults. An independent analysis of the 102 interviews was performed by a jury of two psychologists (both faculty) and a final group co-resolution, regarding the categories, was made.

Representations of the associations between the emergent categories obtained from the narrative analysis, and latent constructs which can work as major determinants in older adults' recognized SA and AtA, were assessed by a Multiple Correspondence Analysis (MCA). Statistic criteria included the following: (a) minimum of 5.0\% of the total variance explained by each factor and (b) minimum eigenvalue of 1 for each factor. Data were analyzed using SPSS for Windows (version 19.0; SPSS Inc., Chicago, IL).

The Portuguese Foundation for Science and Technology (FCT) and ISPA - Instituto Universitário, approved the study. Informed consent was received from all participants and the study protocol was approved by the coordination of Research Unit in Psychology and Health.

\section{Results}

\subsection{Content Analysis of the Emergent Categories}

This study indicates seven categories from the AtA answers emerging from content analysis, namely,(a) "accomplishment, personal fulfilment, and future projects", (b) "occupation, profession, autonomy and leisure", (c) "health status, physical and intellectual functioning", (d) "valorization of time and age", (e) "family, social and interpersonal attachment", (f) "stability, quality and financial situation" and (g) "sense of limit and existential issues".

\subsubsection{Accomplishment, Personal Fulfilment, and Future Projects}

Participants reported accomplishments (e.g., artistic projects), as contributing to AtA. Moreover, older adults verbalized future projects and creative productivity, as a major source of personal fulfilment.

"I need to contribute with something that I am proud of." (Participant 73)

\subsubsection{Occupation, Profession, Autonomy and Leisure}

Profession and occupation were reported by participants as contributing to AtA. To maintain a frequent contact with professional peers was also verbalized as relevant for their AtA. Furthermore, autonomy (e.g., income from their own work) and leisure (e.g., traveling) were indicated by older adults as contributing to their AtA.

"I'm still working as a nurse, three times a week." (Participant 13)

\subsubsection{Health Status, Physical and Intellectual Functioning}

Participants verbalized the importance of being healthy and physically well, as contributing to their AtA.

"I need to be physically well." (Participant 43)

Additionally, participants stressed social security and medical insurance as a requisite for their AtA.

"I believe that any pensioner should have medical insurance to ensure a healthy aging." (Participant 88) 


\subsubsection{Valorization of Time and Age}

Participants verbalized that old(er) age made them perceive life as valuable time. Moreover, they reported that making the most of their time was relevant for their AtA.

"I am aware now that I will not live forever, therefore I want to make the most of my time." (Participant 47)

3.1.5 Family, Social and Interpersonal Attachment

Family, neighbours and friends were reported as contributing to AtA. Moreover, friends often included professional peers.

"It's very important to me to talk to someone that shares the same interests as I do." (Participant 15)

"I love to have my family around me."(Participant 74)

3.1.6 Stability, Quality and Financial Situation

Comfort was verbalized as contributing to these participants' AtA. Moreover, older adults reported the need of life simplification, quality of life and financial stability, as important for their AtA.

"I am very proud of the fact that I am financially independent." (Participant 11)

3.1.7 Sense of Limit and Existential Issues

Participants verbalized the need of integrating the absence of dear ones, and of future death, as contributing to their AtA. Moreover, participants reported that having existential issues and religious beliefs was relevant for their AtA.

"Age helped me integrating the perspective of death." (Participant 6)

"Sense of limit and existential issues" was the most verbalized contributor to AtA for German participants (21.8\%), whereas "accomplishment, personal fulfilment and future projects", "family, social and interpersonal attachment" and "health status, physical and intellectual functioning" were the most mentioned contributors to AtA by Portuguese participants (all 25.4\%), as seen in Table 2.

German participants verbalized their focus on death and existential issues, as contributing to their AtA.

"I know death is close but I live my life as if it was my own Indian summer." (Participant 27)

"I enjoy talking to God." (Participant 71)

Moreover, Portuguese older adults referred projects that presently fulfilled them and the determination to feel accomplished.

“Working on my paintings makes me feel integrated with the world."(Participant 23)

"I'm still working as a doctor and in spite of my family saying that I am too old for working, I don't imagine myself staying at home in front of the TV."(Participant 42)

"I am proud of all my creations. " (Participant 67)

Furthermore, Portuguese participants verbalized that social support and health issues contributed to their AtA.

"Being near my sister is very important to me because it gives me a sense of belonging." (Participant 61)

"Teaching my grandchild makes me feel that I make a difference." (Participant 68)

"All my sensory abilities are well." (Participant 92)

Additionally, findings designated a total of five categories for SA: (a) "in congruence", (b) "without concern", (c) "with apprehension", (d) "young-at-heart" and (e) "good enough".

\subsubsection{In Congruence}

Participants verbalized that they felt in congruence with their present age, as it corresponded to their expectations at the present moment.

"I feel well about my age. I know I am 88 years. I have my house, my daily life, my friends, I feel I can still do everything I want."(Participant 93)

"I feel congruent about my age. I don't avoid thinking about it." (Participant 79)

\subsubsection{Without Concern}

Participants reported no concerns about their age. Moreover, they verbalized that aging was not something that worried them. 
"I don't think about getting old." (Participant 33)

3.1.10 With Apprehension

Participants verbalized concerns about their physical and intellectual autonomy.

"I feel worried about what age will bring me. I'm afraid of losing my autonomy" (Participant 41)

3.1.11 Young-at-heart

A cognisant-childlike posture towards age was reported by the participants.

"Sometimes I feel younger than my grandchildren." (Participant 49)

\subsubsection{Good Enough}

Age was described by participants in a satisfactory way.

"I feel good about my age."(Participant 21)

'Without concern' was the most mentioned SA for Germanparticipants (39.0\%). This and 'young-at-heart' (both $25.5 \%$ ) were the most referred SA for Portuguese older adults (see Table 2).

These participants verbalized that they did not worry about their age and that they felt young.

"I do not think about my age." (Participant 17)

"One thing I learnt over the years is that age does not have to be a burden. I feel my age as something that I don't worry about. Instead I try to enjoy the most of it, without really thinking about it" (Participant 59)

"I still feel young-at-heart." (Participant 86)

Table 2. Emergent categories resulting from content analysis of the pre-categories "subjective age" and "contributors to AtA"

\begin{tabular}{|c|c|c|c|c|c|}
\hline & \multicolumn{2}{|l|}{ German } & \multicolumn{2}{|l|}{ Portuguese } \\
\hline & & $\begin{array}{l}\text { Category } \\
\text { frequency }\end{array}$ & $\begin{array}{l}\text { Category } \\
\text { percentage }\end{array}$ & $\begin{array}{l}\text { Category } \\
\text { frequency }\end{array}$ & $\begin{array}{l}\text { Category } \\
\text { percentage }\end{array}$ \\
\hline \multirow{5}{*}{ Subjective age } & With congruence & 45 & 36.6 & 39 & 23.6 \\
\hline & Without concern & 48 & 39.0 & 42 & 25.5 \\
\hline & With apprehension & 15 & 12.2 & 21 & 12.7 \\
\hline & Young-at-heart & 9 & 7.3 & 42 & 25.5 \\
\hline & Good enough & 6 & 4.9 & 21 & 12.7 \\
\hline $\begin{array}{l}\text { Score of } \\
\text { pre-category } \\
\text { 'subjective age' }\end{array}$ & & 123 & 100.0 & 165 & 100.0 \\
\hline \multirow[t]{7}{*}{ Contributors to aging } & $\begin{array}{l}\text { Family, Social and } \\
\text { Interpersonal Attachment }\end{array}$ & 27 & 9.8 & 48 & 25.4 \\
\hline & $\begin{array}{l}\text { Health status, Physical } \\
\text { and Intellectual } \\
\text { Functioning }\end{array}$ & 12 & 4.3 & 48 & 25.4 \\
\hline & $\begin{array}{l}\text { Occupation, Profession, } \\
\text { Autonomy and Leisure }\end{array}$ & 39 & 14.1 & 24 & 12.6 \\
\hline & $\begin{array}{l}\text { Accomplishment, } \\
\text { Personal Fulfilment and } \\
\text { Future Projects }\end{array}$ & 45 & 16.3 & 48 & 25.4 \\
\hline & $\begin{array}{l}\text { Stability, Quality and } \\
\text { Financial Situation }\end{array}$ & 45 & 16.3 & 9 & 4.8 \\
\hline & $\begin{array}{l}\text { Valorization of Time and } \\
\text { Age }\end{array}$ & 48 & 17.4 & 6 & 3.2 \\
\hline & $\begin{array}{l}\text { Sense of Limit and } \\
\text { Existential Issues }\end{array}$ & 60 & 21.8 & 6 & 3.2 \\
\hline $\begin{array}{l}\text { Score of } \\
\text { pre-category } \\
\text { 'contributors to AtA' }\end{array}$ & & 276 & 100.0 & 189 & 100.0 \\
\hline
\end{tabular}




\subsection{Multiple Correspondence Analysis of the Emergent Categories}

Findings from MCA indicate a model for the pre-categories, with diverse factors and factor loadings and assess the correlational structure of the pre-categories in our study: AtA and SA, for each nationality.

When representing an overall model that joins the concepts of "adjustment" and "age", we considered the correlational structure of the pre-categories in our study (contributors to AtA and SA). The results suggested a three-dimension "adjustment and age" overall model (accounting for $81.0 \%$ of the total variance) composed by: "active", "concentrated", and "attuned", as a best-fit solution (see Table 3) for Portuguese participants and a three-dimension "adjustment and age" overall model (accounting for $87.2 \%$ of the total variance) composed by: "harmonized", "focused", and "young-at-heart", as a best-fit solution for German participants (see Table 4).

Table 3. Three-dimensional representation for "subjective age" and "contributors to AtA" for Portuguese older adults: factor loadings for each dimension, mean loadings and \% inertia (variance) explained

\section{Dimensions}

\begin{tabular}{|c|c|c|c|c|}
\hline Domains & Active & Concentrated & Attuned & Mean \\
\hline With congruence & .675 & .022 & .009 & .235 \\
\hline Without concern & .812 & .001 & .010 & .274 \\
\hline With apprehension & .071 & .638 & .159 & .289 \\
\hline Young-at-heart & .741 & .005 & .048 & .265 \\
\hline Good enough & .022 & .909 & .045 & .325 \\
\hline $\begin{array}{l}\text { Family, Social and Interpersonal } \\
\text { Attachment }\end{array}$ & .775 & .063 & .002 & .280 \\
\hline $\begin{array}{l}\text { Health status, Physical and Intellectual } \\
\text { Functioning }\end{array}$ & .763 & .029 & .032 & .275 \\
\hline $\begin{array}{l}\text { Occupation, Profession, Autonomy and } \\
\text { Leisure }\end{array}$ & .021 & .822 & .079 & .307 \\
\hline $\begin{array}{l}\text { Accomplishment, Personal Fulfilment } \\
\text { and Future Projects }\end{array}$ & .479 & .002 & .143 & .208 \\
\hline $\begin{array}{l}\text { Stability, Quality and Financial } \\
\text { Situation }\end{array}$ & .062 & .008 & .468 & .180 \\
\hline Valorization of Time and Age & .145 & .252 & .507 & .302 \\
\hline Sense of Limit and Existential Issues & .145 & .252 & .507 & .302 \\
\hline Eigenvalue & 4.712 & 3.003 & 2.009 & 3.241 \\
\hline Inertia & .393 & .250 & .167 & .270 \\
\hline$\%$ of Variance & 39.267 & 25.022 & 16.745 & 27.011 \\
\hline
\end{tabular}


Table 4. Three-dimensional representation for "subjective age" and "contributors to AtA" for German older adults: factor loadings for each dimension, mean loadings and \% inertia (variance) explained

Dimensions

\begin{tabular}{|c|c|c|c|c|}
\hline Domains & Harmonized & Focused & Young-at-heart & Mean \\
\hline With congruence & .841 & .049 & .047 & .312 \\
\hline Without concern & .889 & .002 & .008 & .300 \\
\hline With apprehension & .057 & .724 & .112 & .298 \\
\hline Young-at-heart & .281 & .348 & .349 & .326 \\
\hline Good enough & .281 & .348 & .349 & .326 \\
\hline $\begin{array}{l}\text { Family, Social and Interpersonal } \\
\text { Attachment }\end{array}$ & .002 & .932 & .040 & .325 \\
\hline $\begin{array}{l}\text { Health status, Physical and Intellectual } \\
\text { Functioning }\end{array}$ & .125 & .409 & .454 & .329 \\
\hline $\begin{array}{l}\text { Occupation, Profession, Autonomy and } \\
\text { Leisure }\end{array}$ & .126 & .462 & .026 & .205 \\
\hline $\begin{array}{l}\text { Accomplishment, Personal Fulfilment } \\
\text { and Future Projects }\end{array}$ & .568 & .009 & .142 & .239 \\
\hline $\begin{array}{l}\text { Stability, Quality and Financial } \\
\text { Situation }\end{array}$ & .770 & .042 & .037 & .283 \\
\hline Valorization of Time and Age & .611 & .004 & .135 & .250 \\
\hline Sense of Limit and Existential Issues & .685 & .003 & .193 & .294 \\
\hline Eigenvalue & 5.235 & 3.332 & 1.891 & 3.486 \\
\hline Inertia & .436 & .278 & .158 & .291 \\
\hline$\%$ ofVariance & 43.626 & 27.767 & 15.761 & 29.052 \\
\hline
\end{tabular}

\section{Discussion}

The aim of this paper was to bring a fresh perspective to a relevant topic of interest in gerontology. This study prompted the emergence of contributors to AtA. "Sense of limit and existential issues", "accomplishment, personal fulfilment and future projects", "family, social and interpersonal attachment" and "health status, physical and intellectual functioning" were the most frequent contributors to AtA pointed out by this study's participants. As to SA, overall older adults expressed positive SA in $87.5 \%$ of overall narratives). "Without concern" and "young-at-heart" were the most referred SA for older adults.

For the Portuguese participants, the largest factor - "active" - accounted for 39.3\% of total variance, whereas for German participants, "harmonized" represented $43.6 \%$ of total variance. "Attuned" was the least representative factor for Portuguese elderly (16.7\% of total variance) and "young-at-heart" for the German participants (15.8\% of total variance).

The MCA regarding the correlational structure of the two pre-categories, contributors to AtA and SA, emphasizes that these are largely explained by a three-factor "adjustment and age" overall model, for each nationality. Thus, for Portuguese participants, "with congruence", "without concern", "young-at-heart", "family, social and interpersonal attachment", "health status, physical and intellectual functioning" and "accomplishment, personal fulfillment, and future projects", constituted the first factor ("active").

A larger circle of friends is important to provide socializing functions and social activities have been found to be a robust predictor of well-being (Okun, Stock, Haring \& Witter, 1984). Moreover, literature suggests that social relationships are not always supportive and pleasant, as they can, at times, be problematic (Rook, 1984) as attrition in social networks is partially attributed to functional loss, health disparities and the discontinuation of personal relationships (Lang, 2001). 
The second factor ("concentrated") gathered "with apprehension", "good enough" and "occupation, profession, autonomy and leisure". Previous studies indicated that $67.5 \%$ of happiness variance occurs at a within-person level, which can be partly attributed to the time seniors spend on various activities (Oerlemans, Bakker \&Veenhoven, 2011).

Furthermore, growing literature suggested that older adults place a high value on independence - especially when faced with the prospect of being dependent on others for support (Cornwell, 2011) and that success in fulfilling challenges may yield a more positive perceived age (Kleinspehn-Ammerlahn, Kotter-Grühn \& Smith, 2008; Ward, 2010).

Moreover, in our study, the third factor ("attuned") comprised "valorization of time and age", "sense of limit and existential issues:" and: "stability, quality and financial situation"; hence these older adults reflected and balanced time, age, sense of limit and other existential issues, according to existing literature that indicates that older individuals search for existential meaning and conscious aging (Malette \& Oliver, 2006). Moreover, Brandtstädter and Rothermund (2003) stressed the importance of time as an action resource and a source of meaning. The authors suggested that when only a limited residual lifetime remains, the future consequences of actions may be questionable and individuals are therefore likely to shift their goals and value orientations. This theoretical assumption has been supported by a series of studies demonstrating that the experience and awareness that one's lifetime is running out leads to a shift to intrinsic or ego-transcending goals (Brandtstädter, Rothermund, Kranz \& Kühn, 2010).

For German participants living in the community, the first factor ("harmonized") assembled "with congruence", "without concern", "accomplishment, personal fulfillment, and future projects", "stability, quality and financial situation", "valorization of time and age", "sense of limit and existential issues". Literature indicates that productive activities (Wahrendorf \& Siegrist, 2010) and that professional engagement especially with peers (Stevens-Ratchford, 2005; Stevens-Ratchford \& Diaz, 2003), contributed to the well-being of older adults. Moreover, previous literature indicated that the relationship between subjective and objective closeness to death might further be indicative of a self-fulfilling prophecy (Kotter-Grühn, Grühn \& Smith, 2010). That is, those who believe that their time is running out might die earlier because of this belief; they simply 'give up' or lose the will-to-live. In contrast to those who give up, some individuals might never report feeling close to death, which would be in line with the notion that, in general, people suppress or avoid death-related thoughts (Goldenberg \& Arndt, 2008). This could represent either a form of denial (i.e., not being able or willing to admit to oneself that one's time is running out) or optimism, which, in turn, may be adaptive in that this positive attitude contributes to longer survival (Seligman, 2000).

"With apprehension", "family, social and interpersonal attachment" and "occupation, profession, autonomy and leisure" constituted the second factor ("focused"). Growing literature suggested that being active in old age may satisfy various personal needs (Ryan \& Deci, 2000) and that the more a person is able to balance effortful activities with activities that enable recovery on a day-to-day level, the higher the potential happiness a person may experience (Oerlemans, Bakker \&Veenhoven, 2011).

Furthermore, for German elderly living abroad, when family support was not available, more varied forms of support were tapped to meet their needs (e.g., friends, professional peers, neighbors). Despite the fact that no one would doubt that both family and friends play important support functions (Adams \& Blieszner, 1995), recent research suggest friends may be more contributive to well-being in older adults than the family (Cheng, $\mathrm{Li}$, Leung \& Chan, 2011).

The third factor ("young-at-heart") assembled "young-at-heart", "good enough" and "health status, physical and intellectual functioning". Yet, the first two categories (both .349) had a low loading in this factor, which indicated that these categories are not very significant in this factor. It must be noted that social activities, physical activities and cognitive activities do in fact appear to be positively related to psychological well-being among seniors (Oerlemans, Bakker, \& Veenhoven, 2011).

Furthermore, following research will help shed light on the potential of aging well and on AtA. Future work should avoid the limitations of this study. Although our sample size is big enough for a qualitative study, the use of a convenience sample method could have resulted in some selection bias. Sampling of participants was performed with the objective of facilitating the detection of age-specific differences. Thus, normal age group classification was not followed, with resulting difficulty in further comparative analysis. Additionally, the interviews were only semi-structured. Even though the interviews were conducted with a view to being bias free, two core areas were predefined to be addressed. Thus, interviews tended to be steered to these areas which could have biased the results. Moreover, semi-structured interviews were analyzed, employing content analysis. 
Further research should include the triangulation method of grounded theory by combining both qualitative and quantitative analysis (Glaser \& Strauss, 1967; Strauss \& Corbin, 1990). Finally, our findings cannot be generalized to other samples and only reveal the perceptions of our participants. It indicated only relevant clues to take into account in broad assessment for older adults, clinical practice and future research.

Although this sample comprised older adults from 74 to 100 years old, more studies are needed with older adults younger than 74 . The support on variety of aging well presented in this paper is an important contribution to the under-developed potential of the overall model that joins the concepts of "adjustment" and "age" in this population.

Although we have a lot of possible indicators of quality of care, we should go deep in thisdiscussion at EU level, to be able to settle what basic policies versus supplementary policiesare. In brief, we consider the questions about adjustment to the process of aging and SA to be critical aspects for the well-being of the elderly.

\section{Acknowledgements}

We kindly acknowledge the Portuguese Foundation for Science and Technology (FCT), for the grant [grant number SFRH/BD/44544/2008] which supported this research.

Conflict of Interest: The authors report no conflicts of interest. The authors alone are responsible for the content and writing of the paper.

Sponsor's Role: The fund approved the design and aims of the study but did not play any role in the collecting of data, interpretation of results, or preparation of this article.

\section{References}

Adams, R. G., \& Blieszner, R. (1995). Aging well with friends and family. American Behavioral Scientist, 39 , 209-224. http://dx.doi.org/10.1177/0002764295039002008

Al-Janabi, H. N., Flynn, T., \& Coast, J. (2011). Development of a self-report measure of capability wellbeing for adults: The ICECAP-A. Quality of Life Research, 21(1), 167-176. http://dx.doi.org/10.1007/s11136-011-9927-2

Antonovsky, A. (1987). Unraveling The Mystery of Health - How People Manage Stress and Stay Well. San Francisco: Jossey-Bass Publishers.

Barak, B. (2009). Age identity: A cross-cultural global approach. International Journal of Behavioral Development, 33, 2-11. http://dx.doi.org/10.1177/0165025408099485

Bardin, L. (2007). Análise de conteúdo [Content analysis]. Lisboa: Edições 70.

Barrett, A. E. (2005). Gendered experiences in midlife: Implications for age identity. Journal of Aging Studies, 19, 163-183. http://dx.doi.org/10.1016/j. jaging.2004.05.002

Bauer, J. J., \& McAdams, D. P. (2004). Growth goals, maturity, and well-being. Developmental Psychology, 40(1), 114-127. http://dx.doi.org/10.1037/0012-1649.40.1.114

Birren, J. E., \& Schaie, K. W. (1996). Handbook of the psychology of aging. San Diego: Academic Press.

Boult, C., Kane, R. L., Louis, T. A., Boult, L., \& McCaffrey, D. (1994). Chronic conditions that lead to functional limitation in the elderly. Journals of Gerontology Series A: Biological Sciences and Medical Sciences, 49(1), 28-36.

Bowling, A. (1995). What things are important in people's lives? A survey of the public's judgements to inform scales of health-related quality of life. Social Science and Medicine, 41(10), 1447-1462. http://dx.doi.org/10.1016/0277-9536(95)00113-L

Brandstädter, J., \& Greve, W. (1994). The aging self: Stabilizing and protective processes. Developmental Review, 14(1), 52-80. http://dx.doi.org/10.1006/drev.1994.1003

Brandtstädter, J., \& Rothermund, K. (2003). Intentionality and time in human development and aging: compensation and goal adjustment in changing developmental contexts. In: U. M. Staudinger \& U. Lindenberger, (Eds.), Understanding human development: dialogues with lifespan psychology (pp. 105-124). Dordrecht, Netherlands: Kluwer. http://dx.doi.org/10.1007/978-1-4615-0357-6_6

Brandtstädter, J., Rothermund, K., Kranz, D., \& Kühn, W. (2010). Final decentrations: personal goals, rationality perspectives, and the awareness of life's finitude. European Psychologist, 15(2), 152-163. http://dx.doi.org/10.1027/1016-9040/a000019 
Cattell, R. B. (1950). Personality: A systematic theoretical and factual study. New York: McGraw-Hill. http://dx.doi.org/10.1037/10773-014

Cheng, S-T., Li, K-K., Leung, E. M. F., \& Chan, A. C. M. (2011). Social exchanges and subjective well-being: Do sources of positive and negative exchanges matter? Journal of Gerontology Series B: Psychological Sciences and Social Sciences, 66B(6), 708-718. http://dx.doi.org/10.1093/geronb/gbr061

Cornwell, B. (2011). Independence through social networks: Bridging potential among older women and men. Journal of Gerontology Series B: Psychological Sciences and Social Sciences, 66B(6), 782-794. http://dx.doi.org/10.1093/geronb/gbr111

Diener, E., Emmons, R. A., Larsen, R. J., \& Griffin, S. (1985). The satisfaction with life scale. Journal of Personality Assessment, 49, 71-75. http://dx.doi.org/10.1207/s15327752jpa4901_13

Diener, E., Suh, E. M., Lucas, R. E., \& Smith, H. L. (1999). Subjective well-being: Three decades of progress. Psychological Bulletin, 125, 276-302. http://dx.doi.org/10.1037//0033-2909.125.2.276

Eriksson, M., \& Lindstrom, B. (2006). Antonovsky's sense of coherence scale and the relation with health: a systematic review. Journal of Epidemiology and Community Health, 60, 376-81. http://dx.doi.org/10.1136/jech.2005.041616

Fernández-Ballesteros, R. (2010). Quality of life in old age: Problematic issues. Applied Research Quality Life, 6, 21-40. http://dx.doi.org/10.1007/s11482-010-9110-x

Folstein, M. F., Folstein, S. E., \& McHugh, P. R. (1975). Mini-mental state. A practical method for grading the cognitive state of patients for the clinician. Journal of Psychiatric Research, 12, 189-198.

Glaser, B. G., \& Strauss, A. (1967). The discovery of grounded theory: Strategies for qualitative research. Chicago, IL: Aldine Publishing Co.

Goldenberg, J. L., \& Arndt, J. (2008). The implications of death for health: a terror management model for behavioral health promotion. Psychological Review, 115(4), 1032-1053. http://dx.doi.org/10.1037/a0013326

Gwozdz, W., \& Sousa-Poza, A. (2009). Ageing, health and life satisfaction of the oldest old: An analysis for Germany. Bonn: IZA.http://dx.doi.org/10.1007/s11205-009-9508-8

Hancock T., Labonte, R., \& Edwards, R. (1999). Indicators that count! Measuring population health at the community level. Canadian Journal of Public Health, 90, Health Module, 2-26.

Immerfall, S., \& Therborn, G. (2011). Handbook of European societies: Social transformations in the 21st century. Cambridge: Springer.

Instituto Nacional de Estatística. (2000). As gerações mais idosas [The older generations]. Lisboa: DECP /Serviço de estudos sobre a população.

Instituto Nacional Estatística. (2005). Projecções da população residente, NUTS III - 2000 - 2050 [Projections for the residente population, NUTS III-2000-2050]. Lisboa: DECP /Serviço de estudos sobre a população.

Kesebir, P., \& Diener, E. (2010). In pursuit of happiness: Empirical answers to philosophical questions. Perspectives on Psychological Science, 3, 117-125. http://dx.doi.org/10.1111/j.1758-0854.2012.01066.x

Keyes, C. L. M., Shmotkin, D., \& Ryff, C. D. (2002). Optimizing well-being: The empirical encounter of two traditions. Journal of Personality and Social Psychology, 82(6), 1007-1022. http://dx.doi.org/10.1037//0022-3514.82.6.1007

Kleinspehn-Ammerlahn, A., Kotter-Grühn, D., \& Smith, J. (2008). Self-perceptions of aging: Do subjective age and satisfaction with aging change during old age? Journal of Gerontology Series B: Psychological Sciences and Social Sciences, 63B(6), 377-385.http://dx.doi.org/10.1093/geronb/63.6.P377

Kotter-Grühn, D., Grühn, D., \& Smith, J. (2010).Predicting one's own death: the relationship between subjective and objective nearness to death in very old age. European Journal of Ageing, 7(4), 293-300.http://dx.doi.org/10.1007/s10433-010-0165-1

Kozma, A., Stones, M. J., \& McNeil, J. K. (1991). Psychological well-being in later life. Markham: Butterworths.

Lang, F. (2001). Regulation of social relationships in later adulthood. Journal of Gerontology Series B: Psychological Sciences and Social Sciences, 56B(6), 321-326. http://dx.doi.org/10.1093/geronb/56.6.P321

Low, G., \& Molzahn, A. E. (2007). Predictors of quality of life in old age: A cross-validation study. Research in 
Nursing \& Health, 30(2), 141-50.http://dx.doi.org/10.1002/nur.20178

Maddox, G. L., \& Clark, D. O. (1992). Trajectories of functional impairment in later life. Journal of Health and Social Behavior, 33, 114-125. http://dx.doi.org/10.2307/2137250

Malette J., \& Oliver L. (2006). Retirement and existential meaning in the older adult: A qualitative study using life review. Counselling, Psychotherapy, and Health, 2(1), 30-49.

Manton, K. G., Stallard, E., \& Corder, L. (1995). Changes in morbidity and chronic disability in the U.S. elderly population: Evidence from the 1982, 1984, and 1989 National Long Term Care Surveys. Journal of Gerontology Series B: Psychological Sciences and Social Sciences, 50B(4), 194-204. http://dx.doi.org/10.1093/geronb/50B.4.S194

Montepare, J. M. (2009). Subjective age: Toward a guiding lifespan framework. International Journal of Behavioral Development, 33(1), 42-46. http://dx.doi.org/10.1177/0165025408095551

Morse, J. M. (1995). The significance of saturation. Qualitative Health Research, 5(2), 147-149. http://dx.doi.org/10.1177/104973239500500201

Moser, C., Spagnoli J., \& Santos-Eggimann, B. (2011). Self-perception of aging and vulnerability to adverse outcomes at the age of 65-70 years. Journal of Gerontology Series B: Psychological Sciences and Social Sciences, 66B(6), 675-680. http://dx.doi.org/10.1093/geronb/gbr052

Oerlemans, W. G. M., Bakker, A. B, \& Veenhoven, R. (2011). Finding the key to happy aging: A day reconstruction study of happiness. Journal of Gerontology Series B: Psychological Sciences and Social Sciences, 66B(6), 665-674.http://dx.doi.org/10.1093/geronb/gbr040

Okun, M. A., Stock, W. A., Haring, M. J., \& Witter, R. A. (1984). The social activity/subjective well-being relation: A quantitative synthesis. Research on Aging, 6, 245-265.http://dx.doi.org/10.1177/0164027584006001003

Organisation for Economic Co-Operation and Development. (2001). Trends in international migration (Annual Report). Paris: OECD Publishing.

Pavot, W., \& Diener, E. (2004). The subjective evaluation of well-being in adulthood: Findings and implications. Ageing International, 29(2), 113-135. http://dx.doi.org/10.1007/s12126-004-1013-4

Pinsky, J. L., Branch, L. G., Jette, A. M., Haynes, S. G., Feinleib, M., Cornoni-Huntley, J. C., \& Bailey, J. R. (1985). Framingham disability study: Relationship of disability to cardiovascular risk factors among persons free of diagnosed cardiovascular disease. American Journal of Epidemiology, 122(4), 644-656.

Ranzijn, R. (2002). The potential of older adults to enhance community quality of life: Links between positive psychology and productive aging. Ageing International, 27(2), 30-55. http://dx.doi.org/10.1007/s12126-002-1001-5

Rook, K. S. (1984). The negative side of social interaction: Impact on psychological well-being. Journal of Personality and Social Psychology, 46(5), 1097-1108. http://dx.doi.org/10.1037//0022-3514.46.5.1097

Ryan, R. M., \& Deci, E. L. (2000). Self-determination theory and the facilitation of intrinsic motivation, social $\begin{array}{lllll}\text { development and } & \text { Amell-being. }\end{array}$ http://dx.doi.org/10.1037//0003-066X.55.1.68

Ryff, C. D. (1982). Successful aging: A developmental approach. The Gerontologist, 22(2), 209-214. http://dx.doi.org/10.1093/geront/22.2.209

Ryff, C. D. (1989). Beyond Ponce de Leon and life satisfaction: new directions in quest of successful aging. International Journal of Behavioral Development, 12(1), 35-55. http://dx.doi.org/10.1177/ 016502548901200102

Schafer, M. H., \& Shippee, T. P. (2010). Age identity, gender, and perceptions of decline: Does feeling older leads to pessimistic dispositions about cognitive aging? Journal of Gerontology Series B: Social Sciences, 65B(1), 91-96. http://dx.doi.org/10.1093/geronb/gbp046

Seligman, M. E. P. (2000). Optimism, pessimism, and mortality. Mayo Clinic Proceedings, 75, 133-134. http://dx.doi.org/10.1016/S0025-6196(11)64182 -7

Slangen-Dekort, Y. A. W., Midden, J. B. C., Aarts, B., \& Wagenberg, F. V. (2001). Determinants of adaptive behavior among older persons: Self-efficacy, importance, and personal disposition as directive mechanisms. International Journal of Aging and Human Development, 53(4), 253-274. 
Smith, J., Borchelt, M., Maier, H., \& Jopp, D. (2002). Health and well-being in the young old and oldest old. Journal of Social Issues, 58(4), 715-732. http://dx.doi.org/10.1111/1540-4560.00286

Sneed, J. R., \& Whitbourne, S. K. (2003). Identity processing and self-consciousness in middle and later adulthood. Journals of Gerontology: Psychological Sciences, 58(6), 313-319. http://dx.doi.org/10.1093/geronb/58.6.P313

Staudinger, U. M., \& Kunzmann, U. (2005). Positive adult personality development: adjustment and/or growth? European Psychologist, 10(4), 320-329. http://dx.doi.org/10.1027/1016-9040.10. 4.320

Stephan, Y., Caudroit, J., \& Chalabaev. A. (2011). Subjective health and memory self-efficacy as mediators in the relation between subjective age and life satisfaction among older adults. Aging \& Mental Health, 15(4), 428-436. http://dx.doi.org/0.1080/13607863.2010.536138

Stevens-Ratchford, R. G. (2005). Occupational engagement: Motivation for older adult participation. Topics in Geriatric Rehabilitation, 21(23), 171-181.

Stevens-Ratchford, R. G., \& Diaz, T. (2003). Promoting successful aging through occupation: An examination of engagement in life: A look at aging in place, occupation and successful aging. Activities, Adaptation and Aging, 27(4), 19-37.

Strauss, A., \& Corbin, J. (1990). Basics of qualitative research: Grounded theory procedures and techniques. Newbury Park, CA: Sage Publications.

Torres, S. (2003). A preliminary empirical test of a culturally-relevant theoretical framework for the study of successful aging. Journal of Cross-Cultural Gerontology, 18(1), 79-100.

United Nations Population Division. (2002). World Population Ageing 1950-2050. Population and Development Review, 28(4), 814-815.

Wahrendorf, M., \& Siegrist, J. (2010). Are changes in productive activities of older people associated with changes in their well-being? Results of a longitudinal European study. European Journal of Ageing, 7(2), 59-68. http://dx.doi.org/10.1007/s10433-010-0154-4

Ward, R. A. (2010). How old am I? Perceived age in middle and later life. The International Journal of Aging and Human Development, 71(3), 167-184. http://dx.doi.org/10.2190/AG.71.3.a

Ware, J., \& Sherbourne, C. (1992). The MOS 36-item short-form health survey (SF-36). Medical Care, 30(6), 473-483. http://dx.doi.org/10.2190/AG.71.3.a

Watson, D., Clark, L. A., \& Tellegen, A. (1988). Development and validation of brief measures of positive and of positive and negative affect: The PANAS scales. Journal of Personality and Social Psychology, 54(6), 1063-1070. http://dx.doi.org/10.1037/0022-3514.54.6.1063

Wolinsky, F. D., Stump, T. E., Callahan, C. M., \& Johnson, R. J. (1996). Consistency and change in functional status among older adults over time. Journal of Aging and Health, 8, 155-182. http://dx.doi.org/ $10.1177 / 089826439600800201$

World Health Organization Quality of Life Assessment Group. (1995). The World Health Organization Quality of Life assessment (WHOQOL): Position paper from the World Health Organization. Social, Science \& Medicine, 41(10), 1403-1409. http://dx.doi.org/10.1016/0277-9536(95)00112-K

World Health Organization Quality of Life Assessment Group. (2011). World Health Statistics 2011.Geneve, Switzerland: Author. 